\title{
Voice range profile in premutation, mutation, and postmutation of men*
}

\author{
Jaeock Kim ${ }^{1, * *} \cdot$ Seung Jin Lee ${ }^{2}$ \\ ${ }^{I}$ Major in Speech Pathology Education, Graduate School of Education, Kangnam University, Yongin, Korea \\ ${ }^{2}$ Division of Speech Pathology and Audiology, Research Institute of Audiology and Speech Pathology, \\ College of Natural Sciences, Hallym University, Chuncheon, Korea
}

\begin{abstract}
This study compared the voice range profiles (VRPs) with glissando and simplified VRP methods with 57 men who were in premutation ( $8-13$ years), mutation (11-16 years), and postmutation (10-24 years) stages. The difference between modal and falsetto areas measured in two VRP methods was also compared. As the results, the average fundamental frequency (F0) was in the order of premuaton>mutation>postmutation. The maximum F0 (F0max), the range of F0 (F0range), the maximum intensity (Imax), and the range of intensity (Irange) were the lowest in the mutation stage, and these variables were higher in falsetto area than in modal area in both methods. In addition, most variables of VRP in glissando were higher than in simplified VRP, but the differences were not significant. This study showed that, in men in mutation stage, due to the temporary anatomical and physiological changes of the larynx, the mechanism of the vocal folds vibration changes and VRP shows a different pattern from that of other age groups. Both the VRPs of glissando and simplifed VRP are suitable for clinical practice by experienced examiners. And it is necessary to measure not only the falsetto area but also the modal area when measuring VRP.
\end{abstract}

Keywords: puberphonia, voice range profile (VRP), glissando, simplified VRP

1. 서론

이차성징이 발현되는 사춘기에는 신체의 다양한 변화가 일 어난다. 특히 남성의 경우 이차성징으로 인해 후두의 급격한 구 조적 변화가 발생함으로써 발성메카니즘의 변화가 생긴다. 변
성 과정에서 성대와 후두 연골 및 후두근이 불균형적으로 성장 하여 성대의 진동양상이 제한적이고 불안정하게 되고, 호흡에 관여하는 구조물들의 성장으로 인해 음성산출 강도의 변화가 초래된다. 이로 인해 부적절한 음도가 지속적으로 산출되거나 음도조절이 어려워 음도일탈이 빈번하게 나타나며, 고음에서

\footnotetext{
* This work was supported by the Ministry of Education of the Republic of Korea and the National Research of Foundation of Korea (No. NRF2018S1A5A2A03032902).

** jaeock@gmail.com, Corresponding author

Received 2 November 2021; Revised 10 December 2021; Accepted 10 December 2021

(c) Copyright 2021 Korean Society of Speech Sciences. This is an Open-Access article distributed under the terms of the Creative Commons Attribution NonCommercial License (http://creativecommons.org/licenses/by-nc/4.0) which permits unrestricted non-commercial use, distribution, and reproduction in any medium, provided the original work is properly cited.
} 
음성강도를 높이기 어렵다(Kim, 2007a, Wang et al., 1996). 이를 변성발성(voice mutation, puberphonia)이라고 하는데, 변성이 일 어나는 시기는 개인차가 있지만 남성의 경우 대개 9-14세경에 시작되어 13-18세 사이에 완성된다. 변성 기간은 0.5-4년 정도 이고, 평균 약 1.5년이 소요된다(Fuchs et al., 2007; Hollien et al., 1994; Kim, 2007b, Stathopoulos \& Sapienza, 1997; Wang et al., 1996).

아동기에서 변성기를 거쳐 성인기로 전환되는 과정에서 변 화하는 음성을 객관적으로 파악하기 위해서는 발달단계에 따 른 음성의 음향학적 특성을 파악할 필요가 있다. 이에 국내외에 서 많은 연구들이 진행되었는데(Fuchs et al., 2007; Glaze et al., 1988; Ha, 2006; Hollien et al., 1994; Lim, 2014; Kim, 2007a; Kim, 2007b; Ko et al., 2013; Nicollas et al., 2007; Wang et al., 1996; Yun \& Kwon, 1998), 대부분의 연구들이 편안한 모음발성이나 문장 말하기에서의 기본주파수(F0)와 음질을 중심으로 살펴보았다. 그러나 변성기는 음도와 음성강도의 변화가 큰 시기이므로 편 안한 발성뿐 아니라 최대한 산출 가능한 음도와 음성강도를 모 두 살펴봄으로써 최대발성 능력을 파악하는 것이 중요하다.

음도와 강도에 관한 정보를 통합하여 음역대에 관한 최대발 성능력을 살펴보는 음향학적 검사방법으로 음성범위 프로파일 (voice range profile, VRP)이 있다(Kim et al., 2014). VRP는 모음 발성을 통해 최대산출 가능한 기본주파수 범위 내에서 최저부 터 최대음성강도 범위를 측정한다. 포네토그램(phonetogram)이 라고도 불리는 VRP는 주파수와 음성강도의 상관관계를 이차원 도표로 제시하여 시각적 피드백을 제공하기 때문에 음성문제 를 평가하고, 음성치료의 효과를 모니터링하는데 유용하게 사 용된다(Airainer \& Klingholz, 1991; Heylen et al., 1998; Jung et al., 2019).

$\mathrm{VRP}$ 는 일반적으로 모음 발성을 통해 평가하는데, 연구마다 모음 발성 과제를 수행하는 방법이 표준화되어 있지 않고 다양 하다(Berger et al., 2020; Jung et al., 2019; Kim \& Lee, 2019). 반음 (semitone)을 사용하여 각 음도에서 최저 및 최고음성강도 범위 를 측정하기도 하고(Hacki \& Heitmüller, 1999; Heylen et al., 1998; Pieper et al., 2020; Schutte \& Seidner, 1983), 가장 낮은 음 도에서 가장 높은 음도까지 활창을 실시하거나 노래하기를 통 해 측정하기도 한다(Böhme \& Stuchlik, 1995; Hacki, 1996; Lamesch et al., 2008; LeBorgne \& Weinrich, 2003). 그러나 검사 자의 지시 방법이나 대상자의 수행 정도에 따라 측정 결과가 상 이할 수 있다. 특히 반음을 사용하여 측정하는 방법은 최소 20 분에서 1 시간 30 분 정도가 소요되기 때문에 임상에서 사용하는 데 한계가 있다(Hong, 2015; Ma et al., 2007). 이에 최근 성별에 따라 몇 개의 기준음이 되는 기본주파수를 선정하여 최저기본 주파수와 최고기본주파수를 확립하고 각 주파수에서 최저 및 최고음성강도를 측정하는 축약된 $\mathrm{VRP}$ 검사법이 개발되었다 (Jung et al., 2019). 축약된 VRP는 활창에서 측정된 최저 및 최고 기본주파수, 기본주파수범위, 최소 및 최대음성강도, 음성강도 범위와 유의한 차이가 있었고, 전통적으로 사용되는 반음을 이 용한 VRP와는 대부분의 변수에서 통계적으로 유의한 차이가
없어 축약된 VRP의 타당성과 임상적 유용성이 제시된 바 있다. 또한 측정에 소요되는 시간이 반음을 이용하는 방법에 비해 단 축되기 때문에 제한된 시간 내에 $\mathrm{VRP}$ 를 효과적으로 측정하는 방법으로 제시된다(Jung et al., 2019).

변성기 음성은 일시적으로 발생하는 정상적인 과정으로, 이 러한 변화에 적응하지 못하고 병적인 상태가 지속되면 성인기 까지 고음이 산출되는 변성발성장애(mutational falsetto)로 발전 할 수 있다. 변성발성장애는 진성보다 가성발성이 주된 특징으 로 기식성의 쉰 소리가 나고, 음이탈(pitch break)이 잦다. 또한 변성발성장애가 있는 경우 일반 성인과 달리 음역대(vocal register)가 상향하는 특성을 보인다(Dagli et al., 2008). 음성강도 는 전반적으로 감소하고 최고 및 최저주파수의 영역이 상승하 게 된다.

이처럼 변성기 남성의 음성 특성을 파악하기 위해서는 이들 의 음역대를 살펴볼 필요가 있다. 변성 단계에 있는 남성의 음 성문제가 자연스러운 변성 과정에 의한 것인지 또는 다른 음성 장애로 인해 야기된 것인지를 판별하기 위해 변성 과정에 있는 남성의 VRP 정상 범위를 살펴볼 필요가 있는 것이다. 그러나 국 내외 변성기의 VRP에 관한 연구는 그리 많지 않다. 변성이전 단 계와 변성 단계의 6-12세 전후 아동을 대상으로 한 연구가 대부 분이고(Böhme \& Stuchlik, 1995; Hacki \& Heitmüller, 1999; Heylen et al., 1998; Moon \& Han, 2007; Pribuisiene et al., 2011; Schneider et al., 2010; Wuyts et al., 2002, 2003). 변성이전, 변성 및 변성이후 단계의 VRP를 함께 살펴본 연구는 Hwang(2018)이 유일하다. 이 연구에서는 변성 전 남아(9-12세), 변성기(13-16 세), 변성 후(21-22세)의 남성들을 대상으로 반음을 이용한 VRP 를 통해 가성구를 포함한 음역대를 비교하였다.

반음을 이용한 $\mathrm{VRP}$ 는 측정하는데 많은 시간이 소요되므로 상대적으로 짧은 시간에 효율적으로 실시할 수 있는 모음 활창 이나 축약된 VRP를 이용하여 정상적인 변성 과정에 있는 청소 년기 남성의 음역대가 변성기 이전이나 이후와 차이가 있는지 비교할 필요가 있다. 다만 정상 성인의 활창과 축약된 VRP를 비 교한 선행연구(Jung et al., 2019; Kim \& Lee, 2019)에서 두 과제 간에 일부 측정치들이 유의한 차이를 보였기 때문에 변성기와 변성기 전후 남성의 최대발성능력을 측정하기에 어떤 과제가 유용한지도 살펴보아야 한다.

또한 VRP 측정 시 일반적으로 가성구 범위를 포함한 음역대 를 측정하는데, 가성이나 음성일탈이 빈번한 변성 과정에서는 진성구의 음역대도 함께 살펴보아야 할 것이다.

이에 본 연구는 변성 과정 남성의 음역대 특성을 살펴보기 위 해 변성이전(premuation), 변성(mutation), 변성이후(postmutation) 단계에 있는 남성 간의 음역대 차이를 비교하기 위해 활창과 축 약된 VRP를 측정하고, 활창과 축약된 VRP 과제 중 어떠한 과제 가 이들의 음역대를 측정하는데 적합한지 살펴보고자 한다. 또 한 최고기본주파수와 최대음성강도에서 진성구와 가성구를 구 분하여 변성 단계별로 이들 간의 차이가 있는지도 살펴보고자 한다. 


\section{2. 연구방법}

\section{1. 대상자}

본 연구는 서울 또는 경기도에 거주하고 표준어를 사용하는 만 8-24세의 변성이전 단계 아동(21명), 변성 단계 청소년(16명) 및 변성이후 단계 청소년과 성인(20명) 남성을 대상으로 하였 다. 변성의 기준은 대상자나 보호자의 보고에 의해 최근 1 년 이 내에 사춘기와 관련된 신체 변화가 나타나고 목소리 톤이 예전 에 비해 낮아지며 음도일탈을 자주 경험하는 남성들 중 검사자 가 청지각적으로 평가하여 자발화 산출 시 불안정한 음도와 빈 번한 음도일탈이 지각되는 경우로 하였다. 각 집단의 평균 연령 과 연령 분포는 표 1 에 제시하였다.

대상자 선정기준은 흡연력이 없고, 성악훈련을 받지 않았으 며, 과거력상 후두질환, 청각장애, 심장/호흡기질환 및 신경계 질환의 병력이 없고, 최근 2 주간 호흡기질환을 경험하지 않은 사람으로 청력계(동보 DB- 1500 , 서울)를 이용한 순음청력검사 $(500 \mathrm{~Hz}, 1,000 \mathrm{~Hz}, 2,000 \mathrm{~Hz}, 4,000 \mathrm{~Hz}$ 에서 각 $20 \mathrm{~dB})$ 에서 정상 청력으로 평가된 경우로 하였다. 또한 대상자가 $/ \mathrm{a} /$ 모음연장발 성과 자발화를 산출하는 동안 검사자가 평가한 GRBAS 척도 (Hirano, 1981)에서 G가 0 인 경우로 제한하였으나 변성 단계의 경우 변성발성으로 인한 음도일탈과 같은 비정상적 음도가 관 찰되는 경우는 포함하였다.

표 1. 대상자 연령 정보

Table 1. Age information of participants

\begin{tabular}{c|c|c|c}
\hline & $\mathrm{n}$ & $\mathrm{M} \pm \mathrm{SD}(\mathrm{yr})$ & Range (yr) \\
\hline Premutation & 21 & $10.10 \pm 1.26$ & $8-13$ \\
\hline Mutation & 16 & $13.31 \pm 1.40$ & $11-16$ \\
\hline Postmutation & 20 & $19.40 \pm 2.39$ & $17-24$ \\
\hline
\end{tabular}

\section{2. 자료수집}

대상자와 관련된 모든 자료 수집은 강남대학교 기관생명윤 리위원회의 심의를 받아 진행하였다(KNU-HR2004003). 만 811 세 아동은 부모와 함께 음성검사실에 내원하도록 하였으며, 만 18세 미만 미성년자는 부모를 동반하지 않은 경우에 부모가 동의서에 서명한 경우만 참여하도록 하였다. 모든 음성 녹음은 녹음 전 소음측정기(Sound Meter, Abc Apps)로 환경소음을 측정 하여 $30 \mathrm{~dB}$ 이하의 소음이 통제된 경우에만 실시하였고, 대상자 는 의자에 편안한 자세로 앉은 다음 목을 바로 세운 자세에서 정면을 바라보게 한 후에 입으로부터 $10 \mathrm{~cm}$ 떨어져 고정된 단 일지향성 다이나믹 유형의 마이크(Shure SM58, Shure, Niles, IL, USA)에 대고 음성을 산출하도록 하였다.

\subsection{1. 음질 평가}

음질 평가는 대상자가 $/ \mathrm{a} /$ 모음연장발성과 자발화를 산출하 는 동안 음성장애 관련 임상 및 교육경력이 10 년 이상인 1 급 언 어재활사 1 명과 2 급 언어재활사 1 명이 음성을 녹음하는 동안과 녹음된 음성을 듣고 2 회에 걸쳐 실시하였으며, 두 평가자 모두
$\mathrm{G}$ 가 0 으로 평가한 경우만 포함하였고, 변성 단계의 경우 변성 발성으로 인한 음도일탈과 같은 비정상적 음도가 관찰되는 경 우는 본 연구의 대상에 포함하였다.

\subsection{2. 모음연장발성}

대상자의 습관적 $\mathrm{F} 0$ 를 측정하기 위해 모음연장발성 과제를 실시하였다. “안녕하세요. $\mathrm{OOO}$ 입니다.”를 편안하게 말하게 하 고, 다시 숨을 들이마신 후 발화한 문장의 음도와 음성강도로 편안하게 /a/ 모음을 3 초간 연장 발성하도록 하였다. 음성은 마 이크를 통해 MDVP(KayPentax, Lincoln Park, NJ, USA) 프로그 램에 녹음하였다.

\subsubsection{Voice range profile (VRP) 과제}

$\mathrm{VRP}$ 를 측정하기 위해 국내에서 많이 사용되고 있는 활창 (glissando)과 최근 개발된 축약된 VRP 과제를 실시하였고, CSL 의 VRP(Model 4326 Ver.4.0.0, KayPentax) 프로그램으로 녹음하 였다. 녹음의 표본추출률(sampling rate)은 $44,100 \mathrm{~Hz}$ 이고, pitch 및 energy display rate는 각 A1-G\#6와 50-125 dB SPL이다.

활창은 LeBorgne \& Weinrich(2003)가 제시한 대로 대상자가 편안한 음도와 크기에서 모음 $/ \mathrm{a} /$ 를 발성한 후 산출 가능한 가장 높고 큰 소리까지 한음씩 미끄러지듯이 활주법(glissando)으로 활창하도록 하였고, 다시 편안한 음도와 크기에서 / $\mathrm{a} /$ 를 발성한 후 한음씩 가장 낮고 작은 소리까지 미끄러지듯이 활창하도록 지시하였다(그림 1$)$.

축약된 VRP는 Jung et al.(2019)에서 제시한 7개(남성) 기준음 에서 기본주파수에 해당하는 음을 검사자가 VRP 프로그램의 건반음과 모델링을 통해 제시하고 대상자는 각 음도에서 최소 및 최대음성강도를 발성하며, 그 다음으로 낮은 기준음을 제시 하여 대상자가 최소 및 최대음성강도로 발성하도록 하였다(그 림 2). 대상자가 제시된 기준음을 발성하기 어려워할 경우 직전 에 산출한 기준음에서 반음씩 올라가거나 내려가 최대 및 최저 기본주파수를 확립하였다.

활창과 축약된 VRP 과제 모두 검사자가 시연한 것을 대상자 가 따라서 충분히 연습하도록 한 후에 각 과제를 2회씩 반복 실 시하였다. 각 과제별로 가성을 포함하여 최대한 높고 큰 소리를 낼 수 있는 데까지 대상자가 가장 낮거나 높은 음역대에서 충분 한 발성을 산출하지 못하였다고 판단될 경우 그 음역대에서 추 가로 발성하도록 하였다. 각 과제에서 가성을 포함한 최고기본 주파수 범위까지 산출하도록 유도하면서 음질의 변화가 있는 주파수를 진성과 가성의 구분이 되는 지점으로 하였다. 


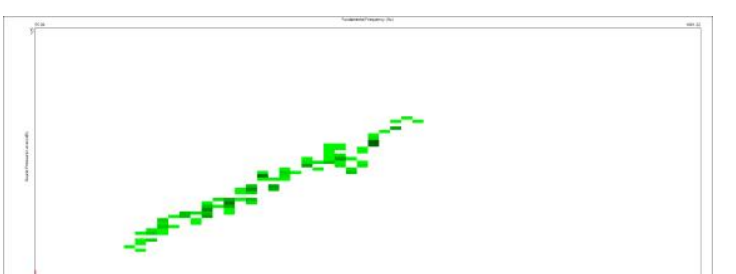

| || |I || || || || || || |I| || ||

VRP, voice range profile.

그림 1. 활창을 이용한 VRP 예시

Figure 1. An example of VRP with glissando

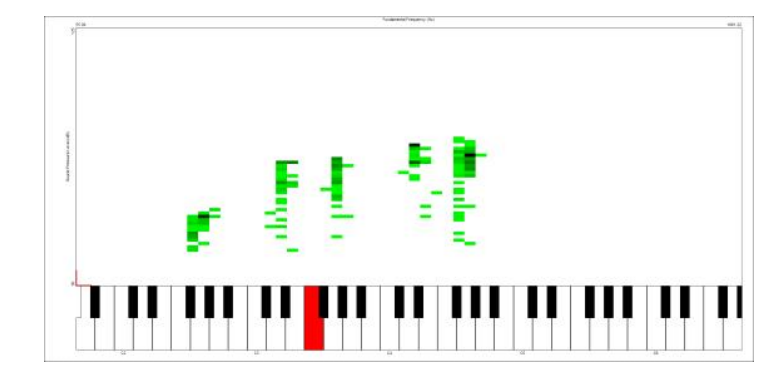

VRP, voice range profile.

그림 2. 축약된 VRP 예시

Figure 2. An example of simplified VRP

\section{3. 자료분석}

각 과제에서 평균기본주파수(F0), 최고기본주파수(F0max), 최저기본주파수(F0min), 기본주파수범위(F0range), 최대음성강 도(Imax), 최소음성강도(Imin), 음성강도범위(Irange)를 산출하 였다. 또한 각 과제에서 F0max, Imax, F0range, Irange는 진성구 (modal)와 가성구(falsetto) 범위를 구분하여 분석하였고(Hacki, 1996), 음도일탈이 있는 지점은 이를 삭제하고 분석하였다. F0max와 Imax는 진성구와 가성구를 구분하여 각 성구(register) 별 최대로 발성할 수 있는 지점을 측정하였는데, 진성구에서 가 성구로 전환되는 지점은 대상자가 최대 음도까지 산출하는 과 정에서 검사자가 청지각적으로 평가하였을 때 성구의 전환으 로 인한 음질의 변화가 있고 음성강도가 갑자기 낮아지는 지점 으로 하였다.

모든 변수(F0, F0max, F0min, F0range, Imax, Imin, Irange)를 2 회 측정한 값들의 평균값에 대한 평균과 표준편차를 산출하였 다. 세 집단의 2가지 VRP 측정방법(활창과 축약된 VRP)에서 진 성구와 가성구를 구분하여 산출한 변수들의 차이를 비교하기 위하여 각 변수별로 집단 간 변수를 집단(변성이전, 변성 및 변 성이후 단계), 집단 내 변수를 과제(활창과 축약된 $\mathrm{VRP}$ 의 진성 구 및 가성구)로 하는 이원반복측정분산분석(repeated measures two-way ANOVA)을 실시하였다. Mauchly의 구형성이 가정된 경우는 구형성 가정값을 사용하였고, 구형성 가정이 만족되지 않은 경우는 Greenhous-Geisser값을 사용하였다. 통계적으로 집 단 간에 유의미한 차이를 보이는 변수는 Bonferroni 사후검정을 실시하였고, 집단 내에 유의미한 차이를 보이는 변수는 주효과 분석을 실시하였다.

\section{3. 연구결과}

$/ \mathrm{a} /$ 모음 발성을 통해 측정된 세 집단의 $\mathrm{F} 0$ 의 펑균과 표준편차 는 표 2와 같다. 또한 세 집단에서 과제별 산출한 진성구와 가성 구 VRP의 F0max, F0min, F0range, Imax, Imin, Irange의 기술통계 량은 표 3 과 그림 3 에 있다.

\section{1. 평균기본주파수(F0)}

세 집단의 $\mathrm{F} 0$ 를 비교한 결과, 집단 간에 유의한 차이가 있었 고 $(F=95.017, p<.001)$, 이에 실시한 사후검정에서 $\mathrm{F} 0$ 는 변성이 전-변성 $(p<.001)$, 변성이전-변성이후 $(p<.001)$, 변성-변성이후 $(p=.016)$ 간에 모두 유의한 차이를 보였으며, 변성이전>변성>변 성이후 단계 순으로 낮았다.

표 2. 집단별 평균기본주파수(F0)

Table 2. Mean fundamental frequency(F0) in each group

\begin{tabular}{c|c|c}
\hline Group & $\mathrm{n}$ & Mean F0 $(\mathrm{Hz})$ \\
\hline Premutation & 21 & $237.00 \pm 26.10$ \\
\hline Mutation & 16 & $155.06 \pm 32.68$ \\
\hline Postmutation & 20 & $129.67 \pm 18.86$ \\
\hline
\end{tabular}

\section{2. 최고기본주파수( $\mathrm{F} 0 \mathrm{max})$}

집단과 과제에 따른 $\mathrm{F} 0 \mathrm{max}$ 를 비교한 결과, 집단과 과제 간 상 호작용은 없었고, 집단에 따라 유의한 차이가 나타났으며 $(F=20.231, p<.001)$, 과제에 따라서도 유의한 차이가 있었다 $(F=62.002, p<.001)$.

대응별 비교 결과, $\mathrm{F} 0 \max$ 는 변성이전-변성 $(p<.001)$, 변성이전변성이후 $(p<.001)$ 간에 유의한 차이가 있었으나 변성-변성이후 간 차이는 없었고, 모든 과제에서 변성 $\fallingdotseq$ 변성이후<변성이전 단 계의 순으로 높았다. 활창 진성구-활창 가성구 $(p<.001)$, 활창 진 성구-축약된 VRP 가성구 $(p<.001)$, 축약된 VRP 진성구-활창 가 성구( $p<.001)$, 축약된 $\mathrm{VRP}$ 진성구-축약된 $\mathrm{VRP}$ 가성구 $(p<.001)$ 간에 유의한 차이가 있었으나 두 과제의 진성구 간 및 가성구 간에 유의한 차이는 없었다. F0max는 활창 가성궃ㅊㄱ약된 VRP 가성구<활창 진성구축약된 VRP 가성구 순으로 두 과제 모두 가성구가 진성구에 비해 높았다.

\section{3. 최저기본주파수(F0min)}

집단과 과제에 따른 $\mathrm{F} 0 \mathrm{~min}$ 을 비교한 결과, 집단과 과제 간 상호 작용은 없었으나 집단 간에 유의한 차이가 나타났고 $(F=126.306$, $p<.001)$, 과제 간에도 유의한 차이를 보였다 $(F=26.905, p<.001)$.

대응별로 비교한 결과, $\mathrm{F} 0 \mathrm{~min}$ 은 변성이전-변성 $(p<.001)$, 변성 이전-변성이후 $(p<.001)$, 변성-변성이후 $(p<.001)$ 의 모든 단계 간 에 모두 유의한 차이가 있었으며, 활창과 축약된 VRP 과제 모두 에서 변성이전>변성>변성이후 단계의 순으로 낮았다. 그리고 모든 집단에서 활창의 $\mathrm{F} 0 \mathrm{~min}$ 이 축약된 $\mathrm{VRP}$ 의 $\mathrm{F} 0 \mathrm{~min}$ 보다 유의 하게 낮았다 $(p<.001)$. 
표 3. 집단별 VRP 변수의 기술통계량

Table 3. Descriptive statistics of VRP variables in each group

\begin{tabular}{|c|c|c|c|c|c|}
\hline Variable & Group & Glissando_modal & VRP_modal & Glissando_falsetto & VRP_falsetto \\
\hline \multirow{4}{*}{$\begin{array}{c}\text { F0max } \\
(\mathrm{Hz})\end{array}$} & Premutation & $484.57 \pm 68.73$ & $469.54 \pm 48.15$ & $649.31 \pm 180.39$ & $632.95 \pm 188.34$ \\
\hline & Mutation & $317.42 \pm 58.90$ & $306.67 \pm 65.37$ & $451.05 \pm 149.64$ & $423.30 \pm 154.78$ \\
\hline & Postmutation & $336.54 \pm 35.07$ & $324.03 \pm 34.12$ & $557.96 \pm 172.17$ & $539.22 \pm 115.78$ \\
\hline & Total & $385.71 \pm 94.31$ & $372.77 \pm 89.31$ & $561.61 \pm 184.55$ & $541.22 \pm 175.40$ \\
\hline \multirow{4}{*}{$\begin{array}{c}\text { F0min } \\
(\mathrm{Hz})\end{array}$} & Premutation & $181.25 \pm 25.62$ & $198.34 \pm 23.93$ & $181.25 \pm 25.62$ & $198.34 \pm 23.93$ \\
\hline & Mutation & $118.41 \pm 27.61$ & $129.85 \pm 29.50$ & $118.41 \pm 27.61$ & $129.85 \pm 29.50$ \\
\hline & Postmutation & $86.69 \pm 8.08$ & $94.01 \pm 11.48$ & $86.69 \pm 8.08$ & $94.01 \pm 11.48$ \\
\hline & Total & $130.43 \pm 46.41$ & $142.51 \pm 50.37$ & $130.43 \pm 46.41$ & $142.51 \pm 50.37$ \\
\hline \multirow{4}{*}{$\begin{array}{c}\text { F0range } \\
(\mathrm{Hz})\end{array}$} & Premutation & $303.33 \pm 79.53$ & $271.21 \pm 57.61$ & $468.07 \pm 192.03$ & $434.61 \pm 188.66$ \\
\hline & Mutation & $199.02 \pm 47.81$ & $176.82 \pm 53.22$ & $332.64 \pm 146.48$ & $293.45 \pm 145.71$ \\
\hline & Postmutation & $249.85 \pm 32.84$ & $230.03 \pm 35.35$ & $471.28 \pm 172.32$ & $445.22 \pm 115.04$ \\
\hline & Total & $255.28 \pm 70.84$ & $230.26 \pm 61.75$ & $431.18 \pm 181.25$ & $398.71 \pm 165.26$ \\
\hline \multirow{4}{*}{$\begin{array}{l}\text { Imax } \\
(\mathrm{dB})\end{array}$} & Premutation & $97.50 \pm 6.58$ & $91.24 \pm 9.11$ & $101.79 \pm 7.70$ & $97.52 \pm 7.93$ \\
\hline & Mutation & $96.09 \pm 6.02$ & $93.63 \pm 6.96$ & $99.63 \pm 5.93$ & $96.97 \pm 5.95$ \\
\hline & Postmutation & $104.35 \pm 5.89$ & $102.68 \pm 7.39$ & $107.33 \pm 5.86$ & $105.53 \pm 6.44$ \\
\hline & Total & $99.51 \pm 7.08$ & $95.92 \pm 9.34$ & $103.12 \pm 7.26$ & $100.18 \pm 7.86$ \\
\hline \multirow{4}{*}{$\begin{array}{l}\text { Imin } \\
(\mathrm{dB})\end{array}$} & Premutation & $67.88 \pm 3.74$ & $64.86 \pm 5.11$ & $67.88 \pm 3.74$ & $64.86 \pm 5.11$ \\
\hline & Mutation & $66.06 \pm 3.97$ & $63.66 \pm 5.18$ & $66.06 \pm 3.97$ & $63.66 \pm 5.18$ \\
\hline & Postmutation & $67.78 \pm 4.62$ & $61.33 \pm 5.78$ & $67.78 \pm 4.62$ & $61.33 \pm 5.78$ \\
\hline & Total & $67.33 \pm 4.14$ & $63.28 \pm 5.49$ & $67.33 \pm 4.14$ & $63.28 \pm 5.49$ \\
\hline \multirow{4}{*}{$\begin{array}{l}\text { Irange } \\
(\mathrm{dB})\end{array}$} & Premutation & $29.62 \pm 7.48$ & $26.38 \pm 8.77$ & $33.90 \pm 8.17$ & $32.67 \pm 7.24$ \\
\hline & Mutation & $30.03 \pm 6.24$ & $29.97 \pm 6.14$ & $33.56 \pm 6.23$ & $33.31 \pm 5.99$ \\
\hline & Postmutation & $36.58 \pm 5.10$ & $41.35 \pm 7.60$ & $39.55 \pm 5.04$ & $44.20 \pm 6.26$ \\
\hline & Total & $32.18 \pm 7.06$ & $32.64 \pm 10.05$ & $35.79 \pm 7.12$ & $36.89 \pm 8.43$ \\
\hline
\end{tabular}

VRP, simplified voice range profile; F0max, maximum fundamental frequency; F0min, minimum fundamental frequency; F0range, range of fundamental frequency; Imax, maximum intensity; Imin, minimum intensity; Irange, intensity range.
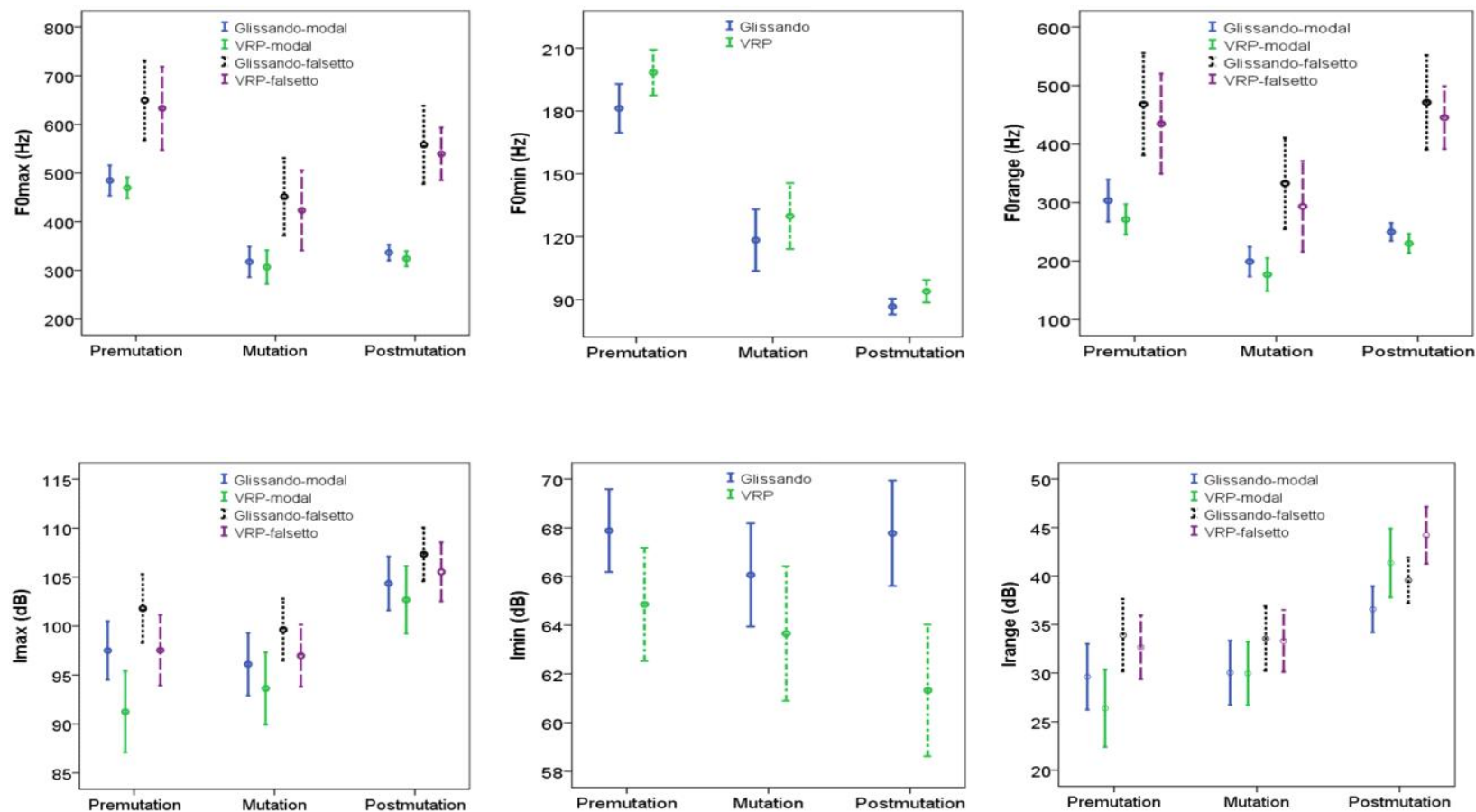

VRP, simplified voice range profile; F0max, maximum fundamental frequency; F0min, minimum fundametnal frequency; F0range, range of fundamental frequency; Imax, maximum intensity; Imin, minimum intensity; Irange, intensity range.

그림 3. 집단과 과제에 따른 VRP 측정 결과

Figure 3. Results of VRP variables by group and task 


\section{4. 기본주파수범위(F0range)}

F0range는 집단과 과제 간 유의한 상호작용이 없었고, 집단 $(F=8.530, p=.001)$ 및 과제에 따른 유의한 차이가 있었다 $(F=62.275, p<.001)$.

대응별 비교 결과, F0range는 변성이전-변성 $(p<.001)$ 과 변성변성이후 $(p<.001)$ 간에 유의한 차이를 보였으며, 변성이전-변성 이후 간에는 유의한 차이가 없었고, 모든 과제에서 변성<변성 이전 $=$ 변성이후 단계 순으로 높았다. 그리고 F0range는 활창 가 성구-축약된 VRP 가성구를 제외한 모든 과제 간에 유의한 차이 를 보였는데, 축약된 VRP 진성구<활창 진성구<활창 가성구 축약된 VRP 가성구 순으로 높았다.

\section{5. 최대음성강도(Imax)}

Imax는 집단과 과제에 따라 유의한 상호작용이 나타나지 않 았으며, 집단에 따라 유의하게 차이가 있었고 $(F=11.030, p=.001)$ 과제에 따른 유의한 차이가 있었다 $(F=38.550, p<.001)$.

대응별 비교 결과, $\operatorname{Imax}$ 는 변성이전-변성이후 $(p<.001)$ 와 변성변성이후 $(p=.001)$ 단계 간 유의한 차이가 있는 반면, 변성이전변성 간에는 통계적으로 유의한 차이 없이 변성이후가 가장 높 았다. Imax는 활창 진성구-축약된 VRP의 가성구 간을 제외한 모든 과제 간에 유의한 차이를 보였는데 $(p<.001)$, 축약된 VRP 진성구<활창 진성구축약된 VRP 가성구<활창 가성구 순으로 높았다.

\section{6. 최소음성강도(Imin)}

집단과 과제에 따른 $\mathrm{Imin}$ 을 비교한 결과, 집단과 과제 간의 유 의한 상호작용이 있었고 $(F=4.650, p=.014)$, 집단 간에는 유의한 차이가 없는 반면 과제 간에 유의한 차이가 있었다 $(F=45.405$, $p<.001)$. 활창의 Imin이 축약된 VRP의 Imin에 비해 높았다.

\section{7. 음성강도범위(Irange)}

Irange는 집단과 과제 간에 유의한 상호작용이 나타났고 $(F=6.789, p<.001)$, 집단 간에도 유의한 차이를 보였으며 $(F=15.793$, $p<.001)$, 과제 간에도 유의한 차이가 있었다 $(F=20.226, p<.001)$.

Irange는 변성이전 $\fallingdotseq$ 변성<변성이후 순으로 높았고, 활창 진성 구축약된 VRP 진성구<활창 가성구축약된 가성구 VRP의 순 으로 두 과제 모두 가성구가 진성구에 비해 높은 반면, 각 측정 방법별 진성구 간과 가성구 간 차이는 없었다.

\section{4. 논의 및 결론}

본 연구는 변성 과정의 남성 음역대 특성을 살펴보기 위해 변 성이전, 변성, 변성이후 단계에 있는 57명의 남성을 대상으로 활창과 축약된 VRP를 사용하여 발성범위 프로파일(VRP)을 비 교하였고, 측정방법별 진성구와 가성구 $\mathrm{VRP}$ 의 차이도 살펴보 았다.

연구결과, 평균기본주파수(F0)는 변성이전 단계가 가장 높았
고 $(237.0 \mathrm{~Hz})$, 변성 단계 $(155.1 \mathrm{~Hz})$, 변성이후 $(129.7 \mathrm{~Hz})$ 단계 순 으로 낮아졌다. 변성기를 중심으로 /a/ 모음 발성 시 F0를 살펴 본 선행연구들을 연령대별로 표 4에 정리하였다. 표 4를 보면, $\mathrm{F} 0$ 는 변성이전 단계가 13 세 미만에서 약 $200-280 \mathrm{~Hz}$, 변성 단계 는 13-15세에서 약 140-180 Hz, 변성이후 단계는 15세 이후에 서 약 100-130 Hz였다. 이는 본 연구결과와 유사하며, 변성기의 이차성징으로 인해 후두구조의 해부생리적 변화로 성대 길이 가 길어지고 질량도 커지면서 음도가 점차 낮아짐을 알 수 있다. 본 연구를 비롯하여 선행연구에 포함된 대상자의 개인차에 따 라 조금씩 차이는 있으나 변성 단계는 13 세경부터 시작되어 16 세경부터는 성인과 유사한 음도가 산출된다는 것을 알 수 있다.

집단 및 과제(활창과 축약된 $\mathrm{VRP}$ 의 진성구 및 가성구)에 따 른 최고기본주파수(F0max), 최저기본주파수(F0min), 기본주파 수범위(F0range), 최대음성강도(Imax), 최소음성강도(Imin), 음 성강도범위(Irange)를 비교한 결과, F0max는 변성변성이후 <변성이전 단계의 순으로 변성이전 단계가 가장 높고 변성 단 계가 가장 낮았다. 반음을 이용하여 변성기 전후 남성의 VRP를 측정한 선행연구들(Appendix 1)을 살펴보면, Hwang(2018)과 Jung et al.(2019)을 제외한 다른 국내외 연구들은 변성이전(아 동) 단계 아동의 음역대에 초점을 두었다. 변성이전 단계의 $\mathrm{F} 0 \mathrm{max}$ 는 최소 $422.3 \mathrm{~Hz}$ 에서 최대 $923.0 \mathrm{~Hz}$ 로 범위가 넓었는데, 이는 다양한 연령에서 측정하였기 때문으로 보이며, 변성이전 단계 남성의 후두가 가장 작아 F0max가 가장 높게 산출될 수 있 음을 알 수 있다. 본 연구에서 변성이전, 변성 및 변성이후 단계 의 축약된 VRP의 F0max는 각 $633.0 \mathrm{~Hz}, 423.3 \mathrm{~Hz}, 539.2 \mathrm{~Hz}$ 로 변 성 단계와 변성이후 단계의 $\mathrm{F} 0 \max$ 간에 통계적으로 유의한 차 이는 없지만 변성 단계에서 가장 낮은 평균값을 보였다. 변성기 는 급격한 후두의 변화가 일어나는 시기로 윤상갑상근이나 갑 상피열근과 같은 음도조절에 관여하는 내후두근의 조절능력이 불완전하다. 이로 인해 변성기 청소년들의 음성산출이 불안정 하고 음도조절이 어려워 최대발성능력이 제한되며 변성이후 성인기에 발성메카니즘이 안정된다는 알 수 있다. 본 연구와는 달리 Hwang(2018)의 연구에서는 연령이 증가할수록 F0max가 감소하였는데, 이는 Hwang(2018)의 연구에서 변성의 기준을 실 제 음성을 듣고 설정한 것이 아니라 연령을 기준으로 하였기 때 문에 변성이후 단계의 남성이 변성 단계에 포함되었을 가능성 있다. 표 4에도 제시되어 있는데, Hwang(2018) 연구에서 변성 단계에 있는 13-16세 남성의 F0 평균이 $117.4 \mathrm{~Hz}$ 로, 이는 변성 이후의 F0와 유사한 값이다. 즉 변성이 일어나는 시기는 신체발 달 속도나 이차성징 출현 속도에 따라 다르므로 변성 단계 음성 을 평가하기 위해서는 연령이 아닌 발성 시 변성 유무를 평가하 여 결정해야 한다. 
표 4. /a/ 모음발성의 한국인 연령대별 기본주파수 기술통계량 Table 4. Descriptive statistics of fundamental frequency by age in Korean during /a/ phonation

\begin{tabular}{|c|c|c|c|c|}
\hline $\begin{array}{l}\text { Author } \\
\text { (year) }\end{array}$ & $\begin{array}{l}\text { Age } \\
(\mathrm{yr})\end{array}$ & Premutation & Mutation & Postmutation \\
\hline \multirow{3}{*}{$\operatorname{Lim}(2014)$} & 4 & $229.78 \pm 22.05$ & & \\
\hline & 5 & $234.20 \pm 48.59$ & & \\
\hline & 6 & $242.41 \pm 20.99$ & & \\
\hline \multirow{2}{*}{$\mathrm{Ha}(2006)$} & 7 & $283.6 \pm 20.7$ & & \\
\hline & 10 & $255.1 \pm 21.5$ & & \\
\hline \multirow{3}{*}{$\begin{array}{l}\text { Hwang } \\
(2018)\end{array}$} & $9-12$ & $204.47 \pm 33.93$ & & \\
\hline & $13-16$ & & $117.35 \pm 14.13$ & \\
\hline & $21-22$ & & & $114.61 \pm 10.28$ \\
\hline \multirow{4}{*}{$\operatorname{Kim}(2007 b)$} & 12 & $222.05 \pm 17.55$ & & \\
\hline & 13 & & $158.89 \pm 27.81$ & \\
\hline & 14 & & $140.90 \pm 23.29$ & \\
\hline & 15 & & & $123.88 \pm 14.88$ \\
\hline \multirow{6}{*}{$\operatorname{Kim}(2007 a)$} & 11 & $239.68 \pm 22.02$ & & \\
\hline & 12 & $226.98 \pm 19.23$ & & \\
\hline & 13 & & $169.30 \pm 25.78$ & \\
\hline & 14 & & $146.76 \pm 22.06$ & \\
\hline & 15 & & & $130.80 \pm 11.22$ \\
\hline & 16 & & & $123.53 \pm 9.20$ \\
\hline \multirow{3}{*}{$\begin{array}{c}\text { Ko et } \\
\text { al.(2013) }\end{array}$} & 16 & & & $107 \pm 10.15$ \\
\hline & 17 & & & $107.18 \pm 9.36$ \\
\hline & 18 & & & $110.10 \pm 11.23$ \\
\hline $\begin{array}{c}\text { Yun \& } \\
\text { Kwon(1998) }\end{array}$ & $5-11$ & $260.24 \pm 22.06$ & & \\
\hline \multirow{7}{*}{$\begin{array}{l}\text { Wang et } \\
\text { al.(1996) }\end{array}$} & 9 & $260.6 \pm 15.6$ & & \\
\hline & 10 & $244.3 \pm 18.3$ & & \\
\hline & 11 & $242.9 \pm 13.9$ & & \\
\hline & 12 & $224.0 \pm 20.2$ & & \\
\hline & 13 & $227.5 \pm 24.1$ & & \\
\hline & 14 & & $182.1 \pm 21.8$ & \\
\hline & 15 & & $155.3 \pm 17.2$ & \\
\hline
\end{tabular}

또한 모든 집단에서 두 과제의 F0max의 진성구 간 또는 가성 구 간에 유의한 차이는 없어 변성기와 변성기 전후 남성의 음역 대를 측정할 때 활창이나 축약된 VRP 중 어떠한 과제를 사용해 도 무방하다는 것을 의미한다. 또한 두 과제 모두 가성구가 진 성구보다 유의하게 높았는데, 가성구와 진성구의 F0max 차이 가 약 120-220 Hz 정도로 음역대를 측정할 때에는 가성구 외에 일반 발화 수준에서의 최대치를 보여주는 진성구의 F0max도 살펴볼 필요가 있음을 보여준다.

변성이후인 청년층을 대상으로 활창과 축약된 $\mathrm{VRP}$ 를 실시 한 Jung et al.(2019)의 연구에서는 축약된 VRP 가성구가 활창 가성구보다 높게 나타나 본 연구의 활창 가성구와 축약된 VRP 가성구 간에 유의한 차이가 없는 것과는 다른 결과를 보였다. Jung et al.(2019)의 연구는 대학생 청년층이 대상인 반면, 본 연 구는 15-24세의 변성기를 막 지난 청소년부터 청년층을 대상으 로 측정하여 두 연구 간 연령대의 차이로 인해 다른 결과가 나 타날 수 있다. 특히 Jung et al.(2019)의 연구에서 활창은 5회 반 복 측정한 결과로 반복 횟수가 많을수록 학습 효과가 커져 수행 력이 높아진다고 하였으나 임상현장에서는 음성검사를 수행하 는 시간이 충분하지 않아 2 회 이상 반복 측정하기 어려우므로 2 회 측정으로 최대음역대를 살펴본 본 연구의 측정치를 기준으
로 살펴보는 것도 바람직할 것이다.

본 연구에서 F0min은 변성이전>변성>변성이후 단계의 순으 로 낮아져 연령이 증가할수록 $\mathrm{F} 0 \mathrm{~min}$ 이 감소한다는 것을 알 수 있다. Appendix 1의 반음을 이용하여 VRP를 측정한 선행연구들 에서 변성이전 단계의 $\mathrm{F} 0 \mathrm{~min}$ 은 최소 $170.9 \mathrm{~Hz}$ 에서 최대 199.2 $\mathrm{Hz}$ 였고, 변성 단계는 $98.7 \mathrm{~Hz}(\mathrm{Hwang}, 2018)$ 였으며, 변성이후 단 계는 Hwang(2018)에서 $88.7 \mathrm{~Hz}$, Jung et al.(2019)의 활창에서 $88.7 \mathrm{~Hz}$ 와 축약된 $\mathrm{VRP}$ 에서 $83.7 \mathrm{~Hz}$ 였다. 본 연구의 변성이전 단 계에서 활창과 축약된 $\mathrm{VRP}$ 의 $\mathrm{F} 0 \mathrm{~min}$ 은 각 $181.3 \mathrm{~Hz}$ 과 $198.3 \mathrm{~Hz}$ 로 선행연구들과 유사하나 변성 단계는 각 $118.4 \mathrm{~Hz}$ 와 $129.9 \mathrm{~Hz}$ 로 Hwang(2018)에 비해 다소 높았고, 변성이후 단계는 각 86.7 $\mathrm{Hz}$ 와 $94.0 \mathrm{~Hz}$ 로 선행연구에서 제시한 측정치와 유사하였다. Hwang(2018)의 연구에 비해 변성 단계에서 다소 높은 F0min은 F0max와 같이 변성 단계에 포함된 대상자의 차이 때문으로 보 인다.

F0max와 F0min의 간격을 나타내는 F0range는 본 연구에서 변성<변성이전 $\fallingdotseq$ 변성이후 단계의 순으로 변성 단계가 가장 낮 았는데, 변성 단계의 불완전한 후두구조와 생리적 특성으로 인 해 최대발성능력이 다른 연령대에 비해 제한적임을 알 수 있다. Appendix 1에 제시한 변성이전 단계의 F0range는 232.3-740.0 $\mathrm{Hz}$ 였고, 본 연구의 활창과 축약된 VRP의 Forange는 각 $468.1 \mathrm{~Hz}$ 와 $434.6 \mathrm{~Hz}$ 로 선행연구들과 유사하였다. 변성이후 단계의 F0range는 Jung et al.(2019)이 제시한 활창 $(546.8 \mathrm{~Hz}$ 과 축약된 $\mathrm{VRP}(679.4 \mathrm{~Hz})$ 보다는 다소 낮았는데, 이러한 차이는 대상자 연 령대의 차이로 인한 수행력 및 과제 반복 횟수의 차이에 의한 것 같다. 또한 Forange는 두 과제 모두 가성구가 진성구에 비해 높았는데, 이는 가성구가 진성구보다 F0max가 높은 반면 가성 구와 진성구 간의 $\mathrm{FOmin}$ 의 차이는 없었던 것에서 기인한다.

다만, 본 연구의 $\mathrm{F} 0 \mathrm{~min}$ 은 진성구와 가성구 모두에서 활창이 축약된 VRP보다 높은 반면, Jung et al.(2019)에서는 축약된 VRP 가 활창보다 높았다. 활창은 음도를 중심으로 산출 가능한 가장 낮은 음도와 가장 높은 음도를 발성하게 하므로 대상자가 용이 하게 산출할 수 있는 반면, 축약된 VRP는 기준으로 선정된 주파 수들에서 최소 및 최대음성강도를 산출하여야 하므로 검사자의 숙련도와 대상자의 이해도가 요구된다. 또한 Jung et al.(2019)의 연구는 활창 과제를 실시할 때 중간에 끊김 없이 활창하도록 지 시함으로써 호흡의 부족으로 인해 최대고음과 최대저음을 충 분히 산출하지 못할 수 있는 반면, 본 연구는 활창 중간에 끊김 이 있어도 대상자에게 최대한 산출할 수 있도록 재시도하도록 하였다. 이러한 이유로 본 연구와 Jung et al.(2019) 간의 차이가 있 을 수 있다. 따라서 활창과 추후 축약된 VRP를 실시할 때 좀 더 명확한 가이드라인과 함께 검사자는 충분한 훈련이 필요하다.

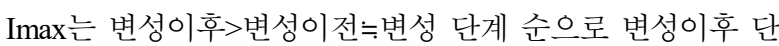
계가 가장 높았는데, 이는 변성이후 단계의 남성은 변성이전이 나 변성 단계에 비해 신체가 커짐에 따라 폐활량이 커져(Wang et al., 1996) 충분한 호흡압력 즉 성문하압을 다른 연령대에 비 해 더 상승시켜 음성강도를 높일 수 있음을 나타낸다. Appendix 1 에서도 유사한 결과를 보이는데, 변성이전 단계의 $\operatorname{Imax}(81.1-$ 
$97.2 \mathrm{~dB})$ 에 비해 변성이후 단계(104.0-120.8 dB)가 높음을 알 수 있다. 또한 $\operatorname{Imax}$ 가 변성이전과 변성 단계 간에 통계적으로 유의 한 차이는 없지만 모든 과제에서 변성 단계가 변성이전 단계에 비해 낮아 변성 단계에서 후두의 급격한 변화로 성문폐쇄와 긴 장도가 감소하고 호흡조절 능력 또한 변화함으로써 음성강도 를 상승시키는데 제한적으로 작용하여 $\operatorname{Imax}$ 가 감소하였다고 볼수 있다.

$\operatorname{Imax}$ 는 두 과제 모두 진성구보다 가성구가 높았지만 진성구 와 가성구 간 $\operatorname{Imax}$ 의 절대값의 차이는 크지 않았다. 이는 음성 강도 조절 메카니즘에 의한 것으로 보인다. 음성강도를 상승시 킬 때 진성구에서는 갑상피열근과 윤상갑상근 조절 및 호흡이 주된 역할을 담당하지만 가성구에서는 성대 길이가 최대한 늘 어나 있는 상태이므로 갑상피열근이나 윤상갑상근의 역할보다 는 호흡의 역할이 더 중요하다(Hirano, 1988). 즉 진성구에서 가 성구로 성구가 전환되면서 음성강도를 최대로 상승시키면 성 문폐쇄율은 다소 감소하지만(Choi et al., 2006) 호흡에 의한 성 문하압은 지속적으로 상승하여 가성구에서도 음성강도를 어느 정도 높일 수 있음을 시사한다. 또한 측정방법에 따른 $\operatorname{Imax}$ 의 차이는 진성구와 가성구 모두에서 활창이 축약된 VRP보다 유 의하게 높았다. 이는 FOrange에서 설명한 바와 같이 활창 실시 방법이나 검사자의 숙련도 차이에서 기인한 것으로 보인다.

Imin은 변성이전, 변성, 변성이후 단계 간에 차이가 없었으며, Hwang(2018)의 연구에서도 집단 간의 유의한 차이가 없어 본 연구와 동일한 결과를 보여준다. 즉 Imin은 발성 시 최소한의 음 성강도로 발성역치압력(phonation threshold pressure) 수준까지 성문하압을 낮추어 산출하는데, 이는 연령에 따라 차이가 없다 는 것을 의미한다. 또한 축약된 VRP가 활창에 비해 낮았는데, 축약된 VRP에서 더 낮은 수준의 음성강도를 산출할 수 있음을 보여주며, Jung et al.(2019)의 연구와도 일맥상통한다.

본 연구의 Irange는 변성이후 단계가 변성이전이나 변성 단계 에 비해 유의하게 높았고, Hwang(2018)의 연구에서도 변성이후 단계의 Irange가 변성이전이나 변성 단계에 비해 유의하게 높은 수치를 보이는 결과와 유사하다. 이는 세 집단 간에 Imin은 차이 가 없는 반면, Imax가 변성이후 단계에서 가장 높은 결과에서 기인한다. 또한 활창과 축약된 VRP 모두에서 가성구가 진성구 에 비해 Irange가 높았는데, 이러한 차이도 Imax와 같이 가성구 에서도 호흡을 통한 성문하압 상승으로 음성강도를 상승시킬 수 있음을 나타낸다. Irange는 활창과 축약된 VRP 간에 차이가 나타나지 않았다.

본 연구결과를 종합해보면, 변성 단계에 있는 남성은 변성기 의 일시적인 후두의 해부학적 및 생리학적 변화로 인해 과도기 적으로 성대가 불안정하게 진동하게 된다. 이로 인해 변성기에 서는 최대로 산출할 수 있는 기본주파수와 음성강도, 기본주파 수범위 및 음성강도범위 등이 감소함으로써 음역대가 감소한 다. 또한 활창과 축약된 VRP를 연령 단계별로 비교했을 때 일부 측정치에서는 활창이 큰 반면 다른 일부에서는 축약된 VRP가 크게 나타났고, 이는 선행연구(Jung et al., 2019)와는 다소 다른 결과이다. 그러나 대부분의 VRP 측정치에서 두 측정방법에 따
른 차이가 크지 않았다. 이는 임상에서 많이 이용하고 있는 활 창을 이용한 VRP와 축약된 VRP를 혼용하여 사용할 수 있음을 시사한다. 다만, 최대발성능력 평가를 위해 활창과 추후 축약된 $\mathrm{VRP}$ 를 실시할 때 좀 더 명확한 가이드라인 제시가 필요하며, 이 를 검사하는 검사자는 충분한 훈련을 실시한 후에 일관성있게 평가하는 것이 필요하다. 이와 더불어 $\mathrm{VRP}$ 측정 시 최대발성범 위를 평가하기 위해 대부분 가성구의 최대범위까지 측정하는 데 진성구 범위의 최대범위도 함께 측정하여 기능적 발성 수준 에서의 최대발성범위도 함께 살펴볼 필요가 있다.

본 연구는 변성 단계 남성의 음역대를 /a/ 모음 발성을 이용한 활창과 축약된 VRP로 다른 연령대와 비교하였다. 추후에는 변 성에 따른 변화를 종단적으로 추적함으로써 변성기의 음성 변 화를 좀 더 명확하게 살펴보아야 할 것이다. 또한 모음 수준에 서가 아닌 발화와 같은 기능적 말산출 시에 변화되는 후두의 메 카니즘이 변성 단계에서는 어떻게 달라지는지를 발화범위 프 로파일(speech range profile, SRP) 등을 통해 살펴볼 필요가 있 다. 본 연구결과는 변성 단계와 전후의 연령대별 VRP의 음향음 성학적 정상 규준치를 마련하기 위한 기초자료로 사용될 수 있 을 것이다.

\section{감사의 글}

자료수집을 위해 수고하신 강남대학교 교육대학원 언어치료 교육전공 최규화, 신승아 선생님께 감사드립니다.

\section{References}

Airainer, R., \& Klingholz, F. (1991). Computerised phonetogram evaluation as a diagnostic aid in functional dysphonia. Laryngo-Rhino-Otologie, 70(7), 362-366.

Berger, T., Fuchs, M., Dippold, S., Meuret, S., Zebralla, V., Yahiaoui-Doktor, M., Wirkner, K., ... Engel, C. (2020). Standardization and feasibility of voice range profile measurements in epidemiological studies. Journal of Voice. Retrieved from https://doi.org/10.1016/j.jvoice.2020.04.014

Böhme, G., \& Stuchlik, G. (1995). Voice profiles and standard voice profile of untrained children. Journal of Voice, 9(3), 304-307.

Choi, S. H., Nam, D. H., Kim, D. W., Kim, Y. H., \& Choi, H. S. (2006). Characteristics of phonatory and respiratory control on pitch, loudness, register change in untrained and trained singers. Journal of the Korean Society of Laryngology, Phoniatrics and Logopedics, 17(2), 115-126.

Dagli, M., Sati, I. Acar, A., Stone Jr, R. E., Dursun, G., \& Eryilmaz, A. (2008). Mutational falsetto: Intervention outcomes in 45 patients. The Journal of Laryngology and Otology, 122(3), 277-281.

Fuchs, M., Fröehlich, M., Hentschel, B., Stuermer, I. W., Kruse, E., \& Knauft, D. (2007). Predicting mutational change in the speaking voice of boys. Journal of Voice, 21(2), 169-178. 
Glaze, L. E., Bless, D. M., Milenkovic, P., \& Susser, R. D. (1988). Acoustic characteristics of children's voice. Journal of Voice, 2(4), 312-319.

Ha, H. R. (2006). School-age children's normative data of acoustic indices for voice evaluation of children with vocal nodule (Master's thesis). Yonsei University, Seoul, Korea.

Hacki, T. (1996). Comparative speaking, shouting and singing voice range profile measurement: Physiological and pathological aspects. Logopedics Phoniatrics Vocology, 21(3-4), 123-129.

Hacki, T., \& Heitmüller, S. (1999). Development of the child's voice: Premutation, mutation. International Journal of Pediatric Otorhinolaryngology, 49, S141-S144.

Heylen, L., Wuyts, F. L., Mertens, F., De Bodt, M., Pattyn, J., Croux, C., \& Van de Heyning, P. H. (1998). Evaluation of the vocal performance of children using a voice range profile index. Journal of Speech, Language, and Hearing Research, 41(2), 232-238.

Hirano, M. (1981). Clinical examination of voice. New York, NY: Springer-Verlag.

Hirano, M. (1988). Vocal mechanisms in singing: Laryngological and phoniatric aspects. Journal of Voice, 2(1), 51-69.

Hollien, H., Green, R., \& Massey, K. (1994). Longitudinal research on adolescent voice change in males. The Journal of the Acoustical Society of America, 96(5), 2646-2654.

Hong, H. (2015). Comparison of vocal ranges by voice and music conditions between the elderly and early adults (Master's thesis). Ewha Womans University, Seoul, Korea.

Hwang, H. J. (2018). Voice and speaking range profile in adolescent men during mutational period (Master's thesis). Kangnam University, Yongin, Korea.

Jung, W. J., Choi, S. H., \& Choi, C. H. (2019). Development and validation of a novel simplified voice range profile measurement method: Comparison of maximum vocal performance based on the VRP protocol. Communication Sciences \& Disorders, 24(3), 770-784.

Kim, S., Pyo, H., \& Gweon, S. (2014). Voice disorders: Theory and practice. Seoul, Korea: Pakhaksa.

Kim, J., \& Lee, S. J. (2019). Development and validation of speech range profile task. Phonetics and Speech Sciences, 11(3), 77-87.

Kim, S. (2007b). Acoustic characteristics on the adolescent period aged from 12 to 15 years (Master's thesis). Hallym University, Chuncheon, Korea.

Kim, S. H. (2007a). Fundamental frequencies of normal children's voice in mutational period. Speech Sciences, 14(4), 251-260.

Ko, H. J., Kang, M. J., Kwon, H. J., Choi, Y., Lee, M. G., \& Choi, H. S. (2013). Acoustic characteristics on the adolescent period aged from 16 to 18 years. Phonetics and Speech Sciences, 5(1), 81-90.

Lamesch, S., Doval, B., \& Castellengo, M. (2008). Phonetograms of laryngeal source parameters for different vowels and laryngeal mechanisms. Journal of the Acoustical Society of America, 123(5), 3243.

LeBorgne, W. D., \& Weinrich, B. D. (2002). Phonetogram changes for trained singers over a nine-month period of vocal training. Journal of Voice, 16(1), 37-43.

Lim, K. (2014). Voice acoustic characteristics of preschool children (Master's thesis). Catholic University of Daegu, Gyeongsan, Korea.

Ma, E., Robertson, J., Radford, C., Vagne, S., El-Halabi, R., \& Yiu, E. (2007). Reliability of speaking and maximum voice range measures in screening for dysphonia. Journal of Voice, 21(4), 397-406.

Moon, K. A., \& Han, J. Y. (2007, May). The features of voice range profile of school-age child. Proceedings of the KSPS Conference (pp. 52-54). Iksan, Korea.

Nicollas, R., Garrel, R., Ouaknine, M., Giovanni, A., Nazarian, B., \& Triglia, J. M. (2007). Normal voice in children between 6 and 12 years of age: Database and nonlinear analysis. Journal of Voice, 22(6), 671-675.

Pieper, L. H., Körner, M., Wiedemann, M., Ludwig, A., Werner, F., Meuret, S., \& Fuchs, M. (2020). Analyzing longitudinal data on singing voice parameters of boys and girls aged 8 to 12.5 and possible effects of a music pedagogical intervention. Journal of Voice. Retrieved from https://doi.org/10.1016/j.jvoice. 2020.07.012 Pribuisiene, R., Uloza, V., \& Kardisiene, V. (2011). Voice characteristics of children aged between 6 and 13 years: Impact of age, gender, and vocal training. Logopedics Phoniatrics Vocology, 36(4), 150-155.

Schneider, B., Zumtobel, M., Prettenhofer, W., Aichstill, B., \& Jocher, W. (2010). Normative voice range profiles in vocally trained and untrained children aged between 7 and 10 years. Journal of Voice, 24(2), 153-160.

Schutte, H. K., \& Seidner, W. (1983). Recommendation by the Union of European Phoniatricians(UEP): Standardizing voice area measurement/phonetography. Folia Phoniatrica et Logopaedica, 35(6), 286-288.

Stathopoulos, E. T., \& Sapienza, C. M. (1997). Developmental changes in laryngeal and respiratory function with variations in sound pressure level. Journal of Speech, Language, and Hearing Research, 40(3), 595-614.

Wang, S. G., Back, M. J., Kim, S. G., Moon, Y. I., Roh, H. J., Goh, E. K., \& Chon, K. M. (1996). The acoustic analysis of pubertal voice change. Korean Journal of Otorhinolaryngology-Head and Neck Surgery, 39(12), 2022-2031.

Wuyts, F. L., Heylen, L., Mertens, F., De Bodt, M., \& Van de Heyning, P. H. (2002). Normative voice range profiles of untrained boys and girls. Journal of Voice, 16(4), 460-465.

Wuyts, F. L., Heylen, L., Rooman, R., Mertens, F., Van de Heyning, 
P. H., Du Caju, M., \& De Bodt, M. (2003). Effects of age, sex, and disorder on voice range profile characteristics of 230 children. Annals of Otology, Rhinology \& Laryngology, 112(6), 540-548.

Yun, S. Y., \& Kwon, D. H. (1998). Acoustic characteristics of normal children's voice of 5 to 11 years old. Journal of Speech \& Hearing Disorders, 7(1), 67-78.

- 김재옥 (Jaeock Kim) 교신저자 강남대학교 교육대학원 언어치료교육전공 교수 경기도 용인시 기흥구 강남로40

Tel: 031-280-3221

Email: jaeock@gmail.com 관심분야: 음성장애, 음성언어의학, 음성과학

- 이승진 (Seung Jin Lee)

한림대학교 자연과학대학 언어청각학부 및 청각언어연구소 교수 춘천시 한림대학길1

Tel: 033-248-2223

Email: sjl@hallym.ac.kr

관심분야: 음성장애, 음성언어의학, 신경말언어장애 
부록 1. 변성이전, 변성 및 변성이후 단계 남성의 음역대에 관한 선행연구 결과(가성구 포함)

\begin{tabular}{|c|c|c|c|c|c|c|c|c|c|c|}
\hline 저자(연도) & $\begin{array}{l}\text { 연령 } \\
\text { (age) }\end{array}$ & 단계 & $\begin{array}{c}\text { 대상자 } \\
\text { (명) }\end{array}$ & $\begin{array}{c}\mathrm{VRP} \text { 측정 } \\
\text { 방법 }\end{array}$ & F0max(Hz) & F0min $(\mathrm{Hz})$ & F0range $(\mathrm{Hz})$ & $\operatorname{Imax}(\mathrm{dB})$ & $\operatorname{Imin}(\mathrm{dB})$ & Irange(dB) \\
\hline \multirow{2}{*}{$\begin{array}{l}\text { Wuyts et } \\
\text { al.(2003) }\end{array}$} & $6-7$ & 변성이전 & 27 & 반음 & $741.0 \pm 29.0$ & 194-6.1 age & $532.0 \pm 30.0$ & $97.2 \pm 1.0$ & $48.6 \pm 0.4$ & $47.9 \pm 1.1$ \\
\hline & $8-11$ & 변성이전 & 26 & 반음 & $923.0 \pm 44.0$ & 194-6.1 age & $740.0 \pm 44.0$ & $101.7 \pm 0.9$ & $48.6 \pm 0.4$ & $53.8 \pm 1.0$ \\
\hline $\begin{array}{c}\text { Moon \& } \\
\text { Han(2007) }\end{array}$ & $10-11$ & 변성이전 & 5 & 반음 & $512.4 \pm 116.0$ & $195.2 \pm 22.5$ & $321.8 \pm 107.8$ & $96.7 \pm 7.9$ & $68.1 \pm 3.6$ & $36.5 \pm 6.2$ \\
\hline $\begin{array}{c}\text { Pribusinene et } \\
\text { al.(2011) }\end{array}$ & $6-13$ & 변성이전 & 31 & 반음 & $734.4 \pm 116.8$ & $199.2 \pm 19.2$ & & 7.2 & \pm 1.4 & \\
\hline \multirow{3}{*}{$\begin{array}{c}\text { Jung et } \\
\text { al.(2019) }\end{array}$} & \multirow{3}{*}{$22.9 \pm 2.1$} & \multirow{3}{*}{ 변성이후 } & \multirow{3}{*}{20} & 반음 & $727.2 \pm 183.1$ & $86.2 \pm 4.8$ & $641.0 \pm 179.6$ & $112.8 \pm 5.9$ & $65.3 \pm 3.8$ & $47.5 \pm 6.1$ \\
\hline & & & & 축약 & $763.1 \pm 206.6$ & $83.7 \pm 4.6$ & $679.4 \pm 203.0$ & $113.0 \pm 6.5$ & $66.3 \pm 3.9$ & $46.8 \pm 9.0$ \\
\hline & & & & 활창 & $635.4 \pm 195.4$ & $88.68 \pm 4.8$ & $546.8 \pm 194.8$ & $104.0 \pm 10.1$ & $72.3 \pm 4.4$ & $31.8 \pm 8.9$ \\
\hline \multirow{3}{*}{ Hwang(2018) } & $9-12$ & 변성이전 & 10 & 반음 & $422.3 \pm 46.0$ & $170.9 \pm 33.7$ & $251.4 \pm 61.8$ & $115.9 \pm 9.7$ & $67.4 \pm 3.6$ & $48.5 \pm 11.2$ \\
\hline & $13-16$ & 변성 & 10 & 반음 & $331.1 \pm 114.1$ & $98.7 \pm 16.9$ & $232.3 \pm 113.6$ & $102.7 \pm 5.1$ & $67.1 \pm 1.7$ & $35.6 \pm 6.1$ \\
\hline & $21-22$ & 변성이후 & 10 & 반음 & $275.2 \pm 53.1$ & $88.7 \pm 13.4$ & \begin{tabular}{|l|}
$186.5 \pm 56.2$ \\
\end{tabular} & $120.8 \pm 9.1$ & $66.2 \pm 3.0$ & $54.6 \pm 8.4$ \\
\hline \multirow{3}{*}{ Current(2021) } & $8-13$ & 변성이전 & 21 & 축약 & $633.0 \pm 188.3$ & $198.3 \pm 24.0$ & $434.6 \pm 188.7$ & $97.5 \pm 7.9$ & $64.9 \pm 5.1$ & $32.7 \pm 7.2$ \\
\hline & $11-16$ & 변성 & 16 & 축약 & $423.3 \pm 154.8$ & $129.9 \pm 29.5$ & $293.5 \pm 145.7$ & $97.0 \pm 6.0$ & $63.7 \pm 5.2$ & $33.3 \pm 6.0$ \\
\hline & $15-24$ & 변성이후 & 20 & 축약 & $539.2 \pm 115.8$ & $94.0 \pm 11.5$ & $445.2 \pm 115.0$ & $105.5 \pm 6.4$ & $61.3 \pm 5.8$ & $44.2 \pm 6.3$ \\
\hline \multirow{3}{*}{ Current(2021) } & $8-13$ & 변성이전 & 21 & 활창 & $649.3 \pm 180.4$ & $181.3 \pm 25.6$ & $468.1 \pm 192.0$ & $101.8 \pm 7.7$ & $67.9 \pm 3.7$ & $33.9 \pm 8.2$ \\
\hline & $11-16$ & 변성 & 16 & 활창 & $451.1 \pm 149.6$ & $118.4 \pm 27.6$ & $332.6 \pm 146.5$ & $99.6 \pm 5.9$ & $66.1 \pm 4.0$ & $33.6 \pm 6.2$ \\
\hline & $15-24$ & 변성이후 & 20 & 활창 & $558.0 \pm 172.2$ & $86.7 \pm 8.1$ & $471.3 \pm 172.3$ & $107.3 \pm 5.9$ & $67.8 \pm 4.6$ & $39.6 \pm 5.0$ \\
\hline
\end{tabular}

VRP, voice range profile. 


\title{
변성이전, 변성 및 변성이후 남성의 발성범위 프로파일*
}

\author{
김 재 옥 $^{1}$ 이 승 진 ${ }^{2}$
}

${ }^{1}$ 강남대학교 교육대학원 언어치료교육전공, ${ }^{2}$ 한림대학교 자연과학대학 언어청각학부 및 청각언어연구소

\begin{abstract}
국문초록
본 연구는 변성 과정의 남성 음역대 특성을 살펴보기 위해 변성이전(21명), 변성(16명), 변성이후(20명) 단계에 있 는 57명의 남성을 대상으로 활창과 축약된 발성범위 프로파일(voice range profile, VRP)을 사용하여 음역 대를 비교 하였다. 또한 측정방법별로 진성구와 가성구 VRP의 차이를 비교하였다. 연구 결과, 평균기본주파수(F0)는 변성이 전>변성>변성이후 순이었고, 최고기본주파수(F0max), 기본주파수범위(F0range), 최대음성강도(Imax) 및 음성강도 범위(Irange)는 변성 단계에서 가장 낮았으며, 가성구가 진성구에 비해 높았다. 또한 대부분의 변수에서 활창이 축 약된 VRP에 비해 높았으나 차이는 유의하지 않았다. 본 연구를 통해 변성 단계에 있는 남성은 변성기의 일시적인 후두의 해부학적 및 생리학적 변화로 인해 성대 진동이 불안정하게 됨으로써 음역대 또한 다른 연령대와 다른 양 상을 보임을 알 수 있었다. 이와 더불어 활창을 이용한 VRP와 축약된 VRP 모두 검사자가 숙련된 경우에 임상에서 모두 사용하기에 적합하며, $\mathrm{VRP}$ 측정 시 가성구 외에도 진성구 범위까지 측정해야 한다는 사실을 확인하였다.
\end{abstract}

핵심어: 변성기, 발성범위 프로파일, 활창, 축약된 VRP

\section{참고문헌}

고혜주, 강민재, 권혁제, 최예린, 이미금, 최홍식(2013). 16 - 18 세 청소년기 음성의 음향음성학적 특성. 말소리와 음성과학, 5(1), 81-90.

김선해(2007a). 변성기 일반 아동 음성의 기본주파수 연구. 말소 리와 음성과학, 14(4), 251-260.

김성태, 표화영, 권순복(2014). 음성장애: 이론과 실체. 박학사: 서울.

김소연(2007b). 12-15세 청소년기 남성 음성의 음향음성학적 특 성. 한림대학교 석사학위논문.

김재옥, 이승진(2019). 발화범위 프로파일 과제 개발 및 타당성 검증. 말소리와 음성과학, $11(3), 77-87$.

문경아, 한지연(2007). 학령기 아동의 음성범위프로필(Voice Range Profile) 특징. 대한음성학회 학술대회논문집(pp. 52-54). 왕수건, 백무진, 김서규, 문영일, 노환중, 고의경, 전경명(1996). 변성기를 전후한 학동의 음성학적 고찰. 한국이비인후과학
회지, 39(12), 2022-2032.

윤선영, 권도하(1998). 5-11세 아동 음성의 음향학적 특성. 언어 치료연구, 7(1), 67-78.

임경선(2014). 학령전기 아동 음성의 음향학적 특성. 대구가톨 릭대학교 석사학위논문.

정원정, 최성희, 최철희(2019). 새로운 축약된 음성범위프로파 일 검사법 개발과 타당도: VRP 프로토콜에 따른 최대 발성 수 행력 비교. 언어청각장애연구, 24(3), 770-784.

최성희, 남도현, 김덕원, 김영호, 최홍식(2006). 성악가와 훈련 받 지 않은 일반인의 음도, 강도, 성구 변화 시 발성 및 호흡조절 특성. 대한음성언어의학회지, 17(2), 115-126.

하현령(2005). 성대결절 아동음성의 음항학적 평가를 위한 정상 음성 기준치 연구. 연세대학교 석사학위논문.

홍혜진(2015). 노인과 초기성인의 음성 및 음악 조건별 음역대 비교. 이화여자대학교 석사학위논문.

황혜진(2018). 변성기 남성의 모음 및 발화 음역대 특성. 강남대 학교 석사학위논문.

\footnotetext{
* 본 연구는 2018년 대한민국 교육부와 한국연구재단의 지원을 받아 수행된 연구임(과제번호: NRF-2018S1A5A2A03032902).
} 